\section{Atraumatiske skuldersmerter i primærhelsetjenesten}

DEBATT

\section{NIELS GUNNAR JUEL}

E-post:n_gj@hotmail.com

Niels Gunnar Juel er spesialist i fysikalsk medisin og rehabilitering og overlege ved Oslo universitetssykehus. Han er dr.philos., lærebokforfatter og lektor ved Avdeling for allmennmedisin, Universitetet i Oslo.

Forfatter har fylt ut ICMJE-skjemaet og oppgir ingen interessekonflikter.

\section{STEIN JARLE PEDERSEN}

Stein Jarle Pedersen er spesialist i allmennmedisin, stipendiat ved Institutt for helse og samfunn, Universitetet i Oslo, og fastlege ved Ankerløkka Legesenter i Fredrikstad. Forfatter har fylt ut ICMJE-skjemaet og oppgir ingen interessekonflikter.

\section{KAIA BECK ENGEBRETSEN}

Kaia Beck Engebretsen er ph.d., spesialfysioterapeut og klinisk spesialist ved Oslo universitetssykehus. Hun forsker på og arbeider med skulderplager.

Forfatter har fylt ut ICMJE-skjemaet og oppgir ingen interessekonflikter.

\section{KJETIL GUNDRO BRURBERG}

Kjetil Gundro Brurberg er ph.d. og seniorforsker ved Folkehelseinstituttet. Han er metodeekspert innen systematiske oversikter og retningslinjer.

Forfatter har fylt ut ICMJE-skjemaet og oppgir ingen interessekonflikter.

\section{OLE MARIUS EKEBERG}

Ole Marius Ekeberg er ph.d., spesialist i fysikalsk medisin og rehabilitering og overlege ved seksjon Fysikalsk medisin og rehabilitering, Helse Fonna. Han forsker på skulderplager. Forfatter har fylt ut ICMJE-skjemaet og oppgir ingen interessekonflikter.

\section{SILJE ENDRESEN REME}

Silje Endresen Reme er psykologspesialist ved Avdeling for smertebehandling, Oslo universitetssykehus, og professor ved Psykologisk Institutt, Universitetet i Oslo. Forfatter har fylt ut ICMJE-skjemaet og oppgir ingen interessekonflikter.

\section{JENS IVAR BROX}

Jens Ivar Brox er spesialist i fysikalsk medisin og rehabilitering, professor ved Universitetet i Oslo og leder av Nakke- og ryggpoliklinikken, Oslo universitetssykehus.

Forfatter har fylt ut ICMJE-skjemaet og oppgir ingen interessekonflikter.

\section{BÅR NATVIG}

Bård Natvig er professor ved Avdeling for allmennmedisin, Universitetet i Oslo. Forfatter har fylt ut ICMJE-skjemaet og oppgir ingen interessekonflikter. 
Vi har laget en retningslinje for håndtering av atraumatiske skuldersmerter i primærhelsetjenesten. Vi legger vekt på god kommunikasjon for å skape trygghet, å gjøre enkel klinisk undersøkelse, å starte enkel behandling og å vurdere enkelte faktorer som kan være viktige for forløpet.

Skuldersmerter er vanlig (1), og en norsk epidemiologisk studie har vist en prevalens på nesten $50 \%$ (2). Skuldersmerter er blant de tre vanligste kontaktårsakene for muskel- og skjelettplager (3) og er en vanlig årsak til sykmeldinger og langvarige sosialytelser (4). Samtidig vet vi at det er store fylkesvise forskjeller i bruken av skulderoperasjoner (5) og sykmeldinger (6).

I Norge er leger, fysioterapeuter og kiropraktorer primærkontakter for muskel- og skjelettplager og bør kunne gjøre en klinisk vurdering og ta beslutning om behandling sammen med pasienten. Det er god dokumentasjon for at behandleren bør ha en pasientsentrert tilnærming for å oppnå best mulige resultater $(7,8)$. Dette innebærer å rette oppmerksomheten mot pasientens bekymringer, preferanser og forventninger i tillegg til de aktuelle symptomene. God kommunikasjon bidrar til at behandler kan oppnå felles forståelse med pasienten og samtidig fremme innsikt og trygghet. Risikofaktorer for langvarige plager kan fanges opp gjennom sykehistorien (9). Enkeltspørsmål kan ha god prediktiv verdi, for eksempel kan man tidlig avdekke symptomer på depresjon og angst (10).

\section{Det enkle er ofte det beste}

I Norge er det ingen nasjonale faglige retningslinjer for skuldersmerter. Vi har laget en retningslinje etter Helsedirektoratets veileder for utvikling av kunnskapsbaserte retningslinjer (11). Den er basert på fire nyere internasjonale retningslinjer supplert med systematiske oversikter og enkeltstudier der dette har vært nødvendig. Målgruppen er alle som behandler skulderpasienter i primærhelsetjenesten. Målet er å bidra til at pasienter med skuldersmerter i primærhelsetjenesten får behandling av god kvalitet basert på best mulig kunnskap. Vi stilte 12 kliniske spørsmål (ramme 1), og anbefalingene er enkle, lite ressurskrevende og i samsvar med kampanjen Gjør kloke valg (12). Styrken på anbefalingene er gradert etter kvaliteten på foreliggende kunnskapsgrunnlag/evidens vurdert med GRADE (Grading of Recommendations Assessment) (13,14), arbeidsgruppens råd og høringsuttalelser (ramme 2). I en artikkel i British Medical Journal fra 2019 basert på nye systematiske oversikter $(15,16)$ anbefales ikke kirurgi ved subakromiale smerter $(17)$. Vår veileder er publisert på Helsebiblioteket.no og gir konkrete anbefalinger ved subakromiale smerter og andre skulderdiagnoser (18).

\section{Ramme 1 Kliniske spørsmål som ble besvart $\mathrm{i}$ arbeidet med retningslinjer for skuldersmerter i primærhelsetjenesten.}

Bakgrunnskunnskap

1. Hva er naturlig forløp ved debut av skuldersmerter?

2. Hvilke risikofaktorer er kjent for utvikling av skuldersmerter?

3. Hvordan er prognosen ved skuldersmerter?

4. Hvilke farlige tilstander er aktuelle ved debut av skuldersmerter og hvilke symptomer og tegn (røde flagg) kjennetegner disse? 
1. Hvilke psykososiale spørsmål med betydning for videre håndtering bør anamnesen avklare?

2. Hvilke kliniske tester med betydning for videre håndtering bør utføres?

3. Når bør radiologiske undersøkelser gjøres?

Behandling

1. Hva er effekten av behandling med NSAID-midler ved skuldersmerter?

2. Hva er effekten av steroidinjeksjon ved skuldersmerter?

3. Hva er effekten av egenøvelser ved skuldersmerter?

4. Hva er effekten av veiledet trening ved skuldersmerter?

5. Hva er effekten av trykkbølgebehandling ved skuldersmerter?

Ramme 2 Kortform av anbefalinger om ulike behandlingstiltak (18).

Anbefalingenes styrke er illustrert med opp-eller nedadvendte piler, én pil for svak anbefaling og to piler for sterk anbefaling.

Hva er effekten av behandling med NSAID-midler ved skuldersmerter?

Ved sterke smerter som hindrer aktivitet anbefales ikke-steroide antiinflammatoriske midler (NSAID) i lavest mulig dose over kortest mulig tid ( $\uparrow)$. Individuelle hensyn til bivirkningsfare må tas.

Hva er effekten av steroidinjeksjon ved skuldersmerter?

Ved frossen skulder foreslås steroidinjeksjon ved sterke smerter $(\uparrow \uparrow)$. Ved subakromiale smerter foreslås steroidinjeksjon dersom det foreligger sterke smerter som hemmer bevegelse $(\uparrow)$. Ultralydveiledning av injeksjonen gir sannsynligvis ingen tilleggseffekt $(\downarrow)$. Vi anbefaler generelt ikke repeterte injeksjoner $(\downarrow)$.

Hva er effekten av egenøvelser ved skuldersmerter?

Instruerte hjemmeøvelser anbefales ved subakromiale smerter $(\uparrow)$. Programmet bør inneholde øvelser for rotatormansjettens og skulderbladets muskulatur og bør sannsynligvis vare i 5-12 uker. Forslag til øvelser er vedlagt i den fullstendige retningslinjen.

Hva er effekten av veiledet trening ved skuldersmerter?

Ved subakromiale smerter anbefales veiledet trening i opptil tre måneder, øvelsene bør inkludere rotatormansjettens og skulderbladets muskulatur $(\uparrow \uparrow)$. Ved frossen skulder er veiledet trening sterkt frarådet $(\downarrow \downarrow)$.

Hva er effekten av trykkbølgebehandling ved skuldersmerter?

Trykkbølgebehandling anbefales ved subakromiale smerter med bløtdelskalk over $5 \mathrm{~mm}$ hvor annen behandling ikke har ført frem $(\uparrow)$. Trykkbølgebehandling anbefales ikke ved uspesifikke skuldersmerter eller subakromiale smerter uten bløtdelskalk $(\downarrow \downarrow)$. 


\section{LITTERATUR:}

1. Luime JJ, Koes BW, Hendriksen IJ et al. Prevalence and incidence of shoulder pain in the general population; a systematic review. Scand J Rheumatol 2004; 33: 73-81. [PubMed][CrossRef]

2. Engebretsen KB, Grotle M, Natvig B. Patterns of shoulder pain during a 14-year follow-up: results from a longitudinal population study in Norway. Shoulder Elbow 2015; 7: 49-59. [PubMed][CrossRef]

3. Linsell L, Dawson J, Zondervan K et al. Prevalence and incidence of adults consulting for shoulder conditions in UK primary care; patterns of diagnosis and referral. Rheumatology (Oxford) 2006; 45: 215-21. [PubMed][CrossRef]

4. Gjesdal S, Holmaas TH, Monstad Ket al. New episodes of musculoskeletal conditions among employed people in Norway, sickness certification and return to work: a multiregister-based cohort study from primary care. BMJ Open 2018; 8: e017543. [PubMed][CrossRef]

5. Helseatlas. Skulderkirurgi (akromionreseksjon) 2015. http://www.helseatlas.no/atlas/39/instant-atlas (14.3.2019).

6. Helde I, Kristoffersen P, Lys $\emptyset$ N et al. Sykefravær: Store fylkesvise forskjeller i varigheten innenfor samme diagnose. Arbeid og Velferd 2010; 38-55.

https://www.nav.no/no/NAV+og+samfunn/Kunnskap/Analyser+fra+NAV/Arbeid+og+velferd/Arbeid+o g+velferd/_attachment/260821?_downloadtrue\&_ts=12cdooe5508 (14.3.2019).

7. Dwamena F, Holmes-Rovner M, Gaulden CM et al. Interventions for providers to promote a patientcentred approach in clinical consultations. Cochrane Database Syst Rev 2012; 12: CDoo3267. [PubMed]

8. Reme SE, Hagen EM, Eriksen HR. Expectations, perceptions, and physiotherapy predict prolonged sick leave in subacute low back pain. BMC Musculoskelet Disord 2009; 10: 139. [PubMed][CrossRef]

9. Laslett M, Steele M, Hing W et al. Shoulder pain in primary care-part 2: predictors of clinical outcome to 12 months. J Rehabil Med 2015; 47: 66-71. [PubMed][CrossRef]

10. Reme SE, Lie SA, Eriksen HR. Are 2 questions enough to screen for depression and anxiety in patients with chronic low back pain? Spine 2014; 39: E455-62. [PubMed][CrossRef]

11. Veileder for utvikling av kunnskapsbaserte retningslinjer. IS-187o. Oslo: Helsedirektoratet, 2012. https://helsedirektoratet.no/Lists/Publikasjoner/Attachments/184/Veileder-for-utvikling-av-kunnskaps baserte-retningslinjer-IS-1870.pdf(14.3.2019).

12. Wærsted D. Choosing Wisely har kommet til Norge. Tidsskr Nor Legeforen 2018; 138: 883.

13. Andrews J, Guyatt G, Oxman AD et al. GRADE guidelines: 14. Going from evidence to recommendations: the significance and presentation of recommendations. J Clin Epidemiol 2013; 66: 719-25. [PubMed][CrossRef]

14. Balshem H, Helfand M, Schünemann HJ et al. GRADE guidelines:3. Rating the quality of evidence. J Clin Epidemiol 2011; 64: 401-6. [PubMed][CrossRef]

15. Lähdeoja T, Karjalainen T, Jokihaara J et al. Subacromial decompression surgery for adults with shoulder pain: a systematic review with meta-analysis. Br J Sports Med 2019; 53: bjsports-2018-100486. [PubMed][CrossRef]

16. Karjalainen TV, Jain NB, Page CM et al. Subacromial decompression surgery for rotator cuff disease. Cochrane Database Syst Rev 2019; 1: CDoo5619. [PubMed]

17. Vandvik PO, Lähdeoja T, Ardern C et al. Subacromial decompression surgery for adults with shoulder pain: a clinical practice guideline. BMJ 2019;364: 1294. [PubMed][CrossRef]

18. Helsebiblioteket. Retningslinje for skulderplager i primærhelsetjenesten.

https://www.helsebiblioteket.no/retningslinjer/skulderplager-i-primaerhelsetjenesten (22.3.2019).

Publisert: 3. april 2019. Tidsskr Nor Legeforen. DOI: 10.4045/tidsskr.19.0116

Mottatt 6.2.2019, første revisjon innsendt 6.3.2019, godkjent 14.3.2019.

(C) Tidsskrift for Den norske legeforening 2020. Lastet ned fra tidsskriftet.no 